\title{
BIOLOGICAL DIFFERENCES BETWEEN SEA WATERS: EXPERIMENTS IN 1954 AND 1955
}

\author{
By Douglas P. Wilson, D.Sc. and F. A. J. Armstrong \\ The Plymouth Laboratory
}

The experiments described and discussed below were made during the 1954 and 1955 breedings seasons of Echinus esculentus. They were a continuation of those made in previous years (Wilson, 195I; Wilson \& Armstrong, 1952, 1954) and were designed to obtain more information concerning the factors responsible for biological differences between sea waters. In spite of the indefiniteness of many results it is considered desirable to publish them now because it does not seem likely that they can be supplemented in the near future, and because they do contain information which may influence further work in this field.

We should again like to express our thanks to the Marine Station at Millport, especially to $\mathrm{Mr} \mathrm{E}$. Latham, for co-operating with us in the collection of water samples.

\section{THE EXPERIMENTS}

Methods did not differ in any material respect from those already described in our earlier papers, with the exception of the sea water extracts used in Expt. 8. In making these sea water was passed slowly through a Berkefeld candle and then through a column of active carbon (copper-free). The carbon was then washed with a little distilled water, dried at room temperature, and extracted with successive small portions of cold pyridine until no further coloured material was removed. The extracts were combined and evaporated in vacuo at room temperature; waxy brown solids were obtained which dispersed readily in water. A 'blank' extract was also made from the untreated carbon. 18.0 1. of E I water gave $0.0547 \mathrm{~g}$ of material which was dispersed in I8 ml. water. I8.5 1 . of Clyde water gave $0.044 \mathrm{I}$ g, which was dispersed in $\mathrm{I} 8.5 \mathrm{ml}$. water. The blank extract was dispersed in $18 \mathrm{ml}$. water. For the experiments $8.0 \mathrm{ml}$. of these concentrates were added to 21 . of artificial sea water.

\section{EXPERIMENT I}

Celtic water collected I2. iii. 54. Ship: R.V. Sarsia with Dr L. H. N. Cooper, position $5 \mathrm{I}^{\circ} \mathrm{II}^{\prime} \mathrm{N}$., $06^{\circ} \mathrm{I}^{\prime} \mathrm{W}$. Strained through $200-$ mesh bolting-silk into carboy. Also two samples filtered through sterile Doulton candles into sterile Winchesters. A sample of bottom water, II $8 \mathrm{~m}$, and a sample of bottom mud, I23 m, were collected with a chromium-plated Nansen Petterson water bottle. The mud with some water was 
kept for 5 days in a glass container and then filtered on a fine paper (previously well washed with sea water from the same station). The mud filtered off was dried and weighed; it amounted to $7 \cdot 2 \mathrm{~g}$ dry matter per litre of sea water. The filtrate is referred to below as 'mud extract'.

E I water collected 12. iii. 54. Ship: M.F.V. Sula with F.A.J.A. Strained through 200-mesh bolting-silk into carboy. Also two samples filtered through sterile Doulton candles into sterile Winchesters.

Clyde water collected I2. iii. 54. Small boat with Mr E. Latham. Strained through 200-mesh bolting-silk into carboy. Also two samples filtered through sterile Doulton candles into sterile Winchesters.

The waters collected in the carboys were further filtered through Doulton candles immediately before use.

The sea-urchins were trawled on 17 March and kept overnight under circulation, the fertilization being made at 4 p.m. on I8 March. Many urchins were opened, almost all had well-filled gonads, few seemed to have spawned. It was with some difficulty that a female with ripe ova in apparently good condition was found. The fertilization was made in a mixture of all three natural waters and the eggs were immediately divided equally between three beakers, and each part washed with six changes of one of the natural waters at room temperature (approx. $15^{\circ} \mathrm{C}$-throughout the experiment the room temperature remained very uniform). The fertilization membranes were well elevated but $\mathrm{I} \frac{1}{4} \mathrm{~h}$ after fertilization the cytoplasm of all the eggs examined (from all three waters) assumed an irregular indented shape, rounding up again shortly before first cleavage. The irregular shapes assumed were varied and striking; such well-marked irregularities were not observed in any of the fertilizations for the later experiments in I954. After first cleavage eggs were distributed in approximately equal numbers to the various dishes comprising the undermentioned sets. Eggs in Sets IV-VI were further washed two changes in their respective presumed sterile waters and it was calculated that only about $0.3 \%$ of the carboy-collected waters, in which the eggs were first washed, would remain in these dishes. Eggs supplied to Sets XIII-XV were taken in equal numbers from all three natural waters in which they had been washed since fertilization, and were further washed in three changes of artificial water before being distributed to the dishes of these sets. Sets XVI and XVII were supplied with eggs washed in E I water.

Set
I
II
III
IV $a$
IV $b$
V $a$
VI $b$
VI $a$
VI $b$
VII
VIII
IX
X
XI
XII
XIII
XIV
XV
XVI
XVII

Celtic water from carboy

E I water from carboy

Clyde water from carboy
Celtic water from Winchester A (proved sterile)

No. of dishes

Celtic water from Winchester B (proved sterile)

E I water from Winchester C (proved sterile)

EI water from Winchester D (not sterile)

Clyde water from Winchester E (not sterile)

Celtic water + I0\% Celtic mud 'extract'

Clyde water + I0\% Celtic mud 'extract'

Celtic water $+10 \%$ Celtic bottom water

E I water + 10\% Celtic bottom water

Clyde water + 10\% Celtic bottom water

Artificial sea water

Artificial sea water + 10\% Celtic mud 'extract'

Artificial sea water $+10 \%$ Celtic bottom water

Celtic mud 'extract' undiluted

Celtic bottom water undiluted

comprising set 
The fertilization was not quite $100 \%$ successful and therefore in every dish there were on the bottom a small number of unfertilized eggs which eventually decayed. The experiment was continued for 7 days. Until 22 March the larvae in all the dishes of any one set were identical as regards swimming vigour, structure and range of variation in structure of the plutei (a proportion were mis-shapen), and in the numbers dead. After that date some variation within a set was observed in some instances, but mostly such differences as did occur were between the larvae of one set and those of another.

The carboy waters from the three localities (Sets I-III) gave almost identical rearings. Not until $22 \mathrm{March}$ was there any definite distinction; on that day the larvae in the Celtic water were rapidly failing in all four dishes. They had begun to fail also in the E I and Clyde waters but not to the same extent. The difference was more marked the next day, although by that time there were differences between dishes within a set. The Clyde water proved to be slightly better for the larvae in these later stages than the E I water. The results with the dishes were confirmed by comparing the larvae left in the wash beakers.

Of the water samples filtered through Doulton candles at the time of collection only three proved to be sterile when the Winchesters were opened just before use. Two of these were from the Celtic sea, the other from E I. In these waters (Sets IV $a$ and $b$, $\mathrm{V} a$ ) the larvae did not do quite so well as in the carboy waters (Sets I-III) but the difference was not great, especially in the $\mathrm{E}$ I water $(\mathrm{Set} \mathrm{V} a)$, where the larvae were only just perceptibly inferior to those in Set II. The three remaining water samples filtered at the time of collection were not sterile. In that from E I (Set V b) the larvae were at all times closely similar to those in Set II. In the Clyde water (Sets VI $a$ and $b$ ) the larvae were inferior to those in the carboy water (Set III), markedly so in Set VI $a$, slightly so in Set VI $b$. These results with both sterile and non-sterile water collected through candles are not entirely satisfactory. The candles were delivered by the maker only the day before the apparatus had to be got ready for use and it is possible that the soaking and washing they were given was insufficiently prolonged to ensure the removal of all soluble substances.

The addition of approximately 10 \% Celtic bottom water to the three natural sea waters and to the artificial (Sets X-XII, and XV) had little or no effect on the larvae reared in them for the first few days, but on and after 22 March a slight though definite improvement was to be seen, the larvae in the waters with the addition failing less rapidly than in those without. On the other hand, the addition of Celtic mud 'extract' while at first slightly stimulating in that on the third day, in all waters to which it had been added (Sets VII-IX and XIV), the larvae were swimming a little more vigorously towards the surface than in the waters without, in the later stages the larvae failed a little more rapidly than in these latter. In the dishes of undiluted Celtic mud 'extract' and Celtic bottom water (Sets XVI and XVII) the larvae were in poor condition even on the second day and in the mud 'extract' they were quickly killed. There is thus shown a graded series: the undiluted mud 'extract' poisonous; the undiluted bottom water harmful but not quite poisonous, the larvae survived in it abnormally for several days; the addition of a small volume of mud 'extract' at first slightly stimulative, but the larvae failed more quickly than in water without; the addition of a small portion of a small volume of bottom water without at first apparent effect, but the larvae survived a little longer than in the waters without.

\section{EXPERIMENT 2}

The difficulty experienced in obtaining good ova for Expt. I led to a fresh batch of sea-urchins being trawled on I9 March I954 and a new fertilization made as soon as they were landed. As before, many ovaries contained irregular fragments of ova. 
A female which looked better than the rest was chosen. After fertilization the eggs were divided into three equal portions and washed in the three kinds of sea water. A sample of the eggs was repeatedly examined until first cleavage, but this time the cytoplasm did not indent irregularly. The only tests made were of the three waters collected in carboys and filtered through Doulton candles just before use.

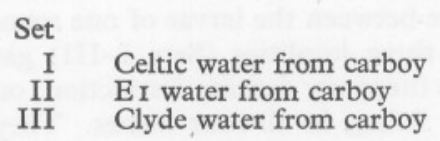

$$
\begin{aligned}
& \text { No. of dishes } \\
& \text { comprising set }
\end{aligned}
$$$$
\begin{aligned}
& \text { E I water from carboy } \\
& \text { Clyde water from carboy }
\end{aligned}
$$

3

3
3

The results were closely similar to those obtained with Sets I-III in Expt. I. The plutei were on the whole more even in structure with fewer mis-shapen individuals than in Expt. I, but they never attained the fine development of plutei in the best rearings in the Celtic and Clyde waters of 1949, I950 and 1952. Five days after fertilization most of them went to the bottom and lost their arms. As in Expt. I the larvae in all three waters were closely similar, but they failed a little earlier in the Celtic water and at the end were a little better in the Clyde water than in the other two, though the difference was no more than perceptible.

\section{EXPERIMENT 3}

E I surface water collected 29. iii. 54. Ship: R.V. Sarsia with F.A.J.A. Strained through 200-mesh bolting-silk into carboy. Also one sample filtered through sterile Doulton candle into sterile Winchester. A sample of water at a depth of $70 \mathrm{~m}$ was collected with a chromium-plated Nansen Petterson water bottle after this bottle had been used for the collection of several samples for hydrographical purposes.

Shortly before use the water collected in the carboy was filtered through a Doulton candle. The water which had passed through a Doulton candle at the time of collection proved to be sterile when the Winchester was opened on I April immediately before the experiment began. The carboy water before filtration gave, on the other hand, a heavy growth of mixed organisms when bacteriologically tested at the same time.

The sea-urchins were trawled on I April and used immediately. Of the many opened only a few were spent. In general the ovaries seemed to be in better condition than a fortnight previously and there was less difficulty in selecting a female for spawning. Immediately after the fertilization was made in $\mathrm{E}$ I surface water the eggs were divided into four equal quantities and each quantity washed with six changes of either E I surface water, E I sterile surface water, E I deep water from $70 \mathrm{~m}$, or four changes of artificial sea water. Before first cleavage took place the cytoplasm of some of the eggs became irregular in outline and slightly indented (but not as markedly as in Expt. I), rounding up again before cleavage. After first cleavage equal quantities of eggs were distributed as follows. There were four dishes in each set, two in each half-set in Series IV and V.

$\begin{aligned} \text { Set } & \\ \text { I } & \text { E I surface water (carboy) } \\ \text { II } & \text { Sterile E I surface water } \\ \text { III } & \text { E I deep water (from } 70 \mathrm{~m} \text { ) } \\ \text { IV } & \text { EI surface water }+50 \% \text { deep water } \\ \text { V } & \text { E I surface water }+ \text { ro\% deep water } \\ \text { VI } & \text { Artificial sea water } \\ \text { VII } & \text { Artificial sea water }+10 \% \text { E I surface water } \\ \text { VIII } & \text { Artificial sea water }+ \text { ro\% E I deep water }\end{aligned}$

Eggs washed between fertilization and first cleavage in

EI surface water Sterile E I surface water EI deep water (a) E I surface water

(b) EI deep water

(a) EI surface water

(b) EI deep water Artificial sea water Artificial sea water Artificial sea water 
The duration of the experiment was about I week. There was little difference in the condition of the larvae between Sets I and II, the water sterile until the experiment began being slightly less favourable than the carboy water. By this time the Doulton candle had been well washed before use.

The deep water (Set III) proved much less favourable than either of the surface waters (Sets I and II); from an early stage the larvae in it were mainly abnormal and in 2 or 3 days many were dead or dying. The mixtures of surface and deep water are of particular interest because the results with them were strikingly different according to whether the eggs were washed between fertilization and first cleavage in surface water or in deep water. With those washed in surface water (Sets IV $a$ and V $a$ ) the results were similar to those with surface water alone (Sets I and II) being only a little less favourable in the $50 \%$ mixture. But with eggs washed in deep water (Sets IV $b$ and $\mathrm{V} b$ ) the larvae were decidedly inferior to surface water Sets I and II and only a little better at first than those in deep water alone (Set III). It will be realized that these results with deep water (which are similar in some respects to those obtained with the bottom water and mud used in Expt. I, but in that experiment eggs did not come into contact with the bottom water until after first cleavage) could be explained by faulty technique if the beaker in which the eggs washed with the deep water had contaminated that water. The beaker had, however, been well cleaned with hot strong sulphuric acid before use, but it was not a new beaker. It could also be explained if the chromium-plated water bottle had affected the water.

The larvae in artificial sea water (Set VI) were poor compared with those in surface water (Sets I and II) although better than those in deep water (Set III). An addition of $10 \%$ surface water affected a slight improvement, while the addition of 10 $\%$ deep water had little or no effect. These were the poorest larvae so far reared in artificial sea water in the course of these experiments; it should perhaps be noted that in earlier experiments the eggs were not washed into artificial sea water quite so soon after fertilization as they were here.

\section{EXPERIMENT 4}

E I surface water collected I2. iv. 54. Ship: M.F.V. Sula with F.A.J.A. Strained through 200-mesh bolting-silk into carboy. The presence of Phaeocystis was noted. Also samples of both surface and deep water from $70 \mathrm{~m}$ collected in plastic-lined water bottle, and stored in Winchesters.

Before use all waters were filtered. That from the carboy was passed through a Berkefeld candle and was used for making the fertilization. The waters from the Winchesters were aerated after passing through the Doulton candles and were used for washing the eggs and for filling the experimental dishes. Thus in this experiment the waters compared had both been collected in the same way. Moreover, the use of the plastic water bottle instead of the chromium plated one used for the experiment would resolve doubts concerning the latter. The beakers used for washing the eggs were new ones, thoroughly cleaned in hot strong sulphuric acid.

The sea-urchins were trawled on I3 April and used at once. The ovaries seemed to be in better condition than last time and almost $100 \%$ after fertilization had wellelevated membranes and even cleavage. No shrinking of the cytoplasm was noted between fertilization and first cleavage. The eggs were divided into two equal parts immediately after fertilization and one lot washed with surface water and the other with deep water, six changes of each. After first cleavage approximately equal numbers of eggs were distributed to the following sets of dishes, four dishes to each set. 


\begin{tabular}{|c|c|c|}
\hline Set & & Eggs washed with \\
\hline & E I surface water & E I surface water \\
\hline II & E I surface water & E I deep water \\
\hline III & E I deep water & E I surface water \\
\hline IV & $\begin{array}{l}\text { E I deep water } \\
\text { Mixture: } 50 \% \text { surface }\end{array}$ & E I deep water \\
\hline VI & Mixture: $\begin{array}{l}50 \% \text { deep water } \\
50 \% \text { surface } \\
50 \% \text { deep water }\end{array}$ & E I surface water \\
\hline
\end{tabular}

In spite of the apparent excellence of the fertilization a considerable proportion of the eggs died during late cleavage stages before the formation of the blastula, and many blastulae were abnormal, only a small proportion appearing normal. That this was not due to the plastic water bottle in which the experimental waters were collected is shown by the fact that the eggs and blastulae were identical in a control Berkefeld filtered water from the carboy, these eggs not having come into contact with water from the plastic water bottle at all. Unfortunately, in this experiment no water other than that from E I was available for comparison, and no fertilization in this water of another batch of eggs and sperm. In spite of these aspects being uncontrolled and of the relatively poor condition of the best larvae the experiment gave a striking result. For the first 2 days after fertilization all dishes in all sets were alike as regards their larval content. The larvae if not already dead, were slow to swim up, most of them remaining on the bottom even as late as the gastrula stage. The majority showed some abnormality, the gastrulae on the whole being small and shrunken. A day later (I6 April) almost all those in deep water (Sets III and IV) were dead and so were those which had been washed in deep water between fertilization and first cleavage, although then put into surface water (Set II-it must be noted that this water would contain about $7.5 \%$ deep water, added to it with the larvae). Only those larvae which had never at any time been in contact with deep water (Set I) were still mainly alive and swimming well, even more vigorously than before and on the whole a little more normal-looking. Sets V and VI with mixed water, whatever water the eggs had been washed with, were in much poorer condition than these, but strangely not quite so bad as Set II with much less deep water mixed with it. This would be understandable for Set V (eggs washed in surface water) if the eggs are specially susceptible to damage between fertilization and first cleavage, and were damaged by the deep water, but would not explain why Set VI (eggs washed in deep water) was better than Set II which contained a much smaller proportion of deep water.

The experiment was not seen again until 20 March. Conditions on that day neither added nor subtracted anything from the result.

\section{EXPERIMENT 5}

Clyde water collected 26. iv. 54 in Largs Channel, tide falling. Small boat with $\mathrm{Mr}$ E. Latham. Strained into carboy through 200-mesh bolting-silk, which was discoloured brown by diatoms.

Artificial sea water. The salts used were the same as in 1953 except for the $\mathrm{CaCl}_{2}$ which was a new batch.

A more elaborate experiment had been planned. Unfortunately, stormy weather prevented the collection of natural sea waters at Plymouth and it was only possible to compare the Clyde water with artificial sea water and to investigate the effect of washing the eggs between fertilization and first cleavage in both waters. The Clyde water was passed through a Berkefeld filter-candle before use.

The sea-urchins were trawled on 28 April and used at once; most of them were spent. The eggs selected gave an almost $100 \%$ fertilization with well-elevated fertiliza- 
tion membranes. Less than $15 \mathrm{~min}$ after adding the sperm the eggs were divided into one of the two waters. Each water was changed six times and after first cleavage the eggs were distributed to the following sets of four dishes each. It should be noted that each dish would receive with the eggs a little of the water in which they had been washed. It was calculated that this water would amount to about $8 \%$ of the total volume of water in the dish.

Set

\section{Clyde water}

III Artificial sea water

IV Artificial sea water

V Mixture in equal proportions of Clyde and artificial sea waters

VI Mixture in equal proportions of Clyde and artificial sea waters
Eggs washed with Clyde water Artificial sea water Clyde water Artificial sea water Clyde water Artificial sea water

In spite of the apparent excellence of the fertilization the blastulae were slow to swim up in all dishes and the majority took an unusually long time to reach the surface and most were beginning to gastrulate before they did so. They developed better in the Clyde water than in the artificial sea water, their development in the mixture being nearly as good, though not quite, as in the Clyde water alone. The kind of water the eggs were washed in between fertilization and first cleavage made no significant difference. In all waters plutei became abnormal by the third or fourth day, earlier and to a greater extent in the artificial sea water than in that from the Clyde water. It has been noted that the latter had a heavy growth of diatoms in it at the time of collection, but as no comparison was made with any other natural sea water it is impossible to decide whether the relatively poor conditions of the larvae at all times in this water is to be attributed to its constitution or to the condition of the eggs or sperm.

\section{EXPERIMENT 6}

Clyde water collected 4. v. 54, in Largs Channel approx. an hour before high tide. Small boat with $\mathrm{Mr}$ E. Latham. Strained into two Winchesters through 200-mesh boltingsilk; hardly any diatoms present. At the same time two further samples (A and B) were collected through Doulton candles into evacuated sterile Winchesters using the method described in Wilson \& Armstrong, 1954, pp. 348-9. Particulars of artificial water as for Expt. V.

Continuing bad weather prevented the collection of natural sea water at Plymouth. This experiment embodied two separate investigations: (I) a further attempt to compare sea water strained only through bolting-silk at the time of collection into clean but non-sterile glass containers, with sea water collected at the same time through Doulton candles into sterile containers and tested for sterility just before use; (2) to investigate the effect of adding a quantity of sea water from which a variety of thick growths of phytoplankton organisms had filtered out. We are indebted to Dr Mary Parke for supplying a number of thick cultures of various diatoms and flagellates for this purpose. These cultures were filtered through Doulton candles. Dr Parke also supplied the sample of unused sterile culture medium ('Erdschrieber') for our controls.

We are indebted to Dr C. H. Jellard, Public Health Laboratory Service, for bacteriological tests of the Clyde waters A and B, these being sampled bacteriologically on 6. v. 54 shortly before the experiment began. At the same time bacteriological samples were taken from the Winchesters which contained the water filtered only through bolting-silk. These latter samples gave heavy growths of a number of different organisms, the waters A and B gave no visible growths for 2 days, but later each gave some growth of a single organism, in each case a slow-growing Gram-negative bacillus, 
a different one in A from that in B. The control plates which had not been inoculated were sterile.

The sea-urchins were trawled on 6. v. 54. Almost all were spent, or partially spent. Only one female in reasonably good condition was obtained and a few males. A fertilization was made in Clyde water filtered from the carboy which supplied Expt. V. The eggs were immediately divided into four equal quantities; one washed with six changes of new Clyde water from the Winchesters (filtered through Doulton candles in the laboratory), two other quantities each with six changes of Clyde waters A and B, and one quantity with six changes of artificial sea water. The temperatures of all waters were adjusted to room temperature before use.

Almost all eggs fertilized and showed good membrane elevation; a few protruded cytoplasm through the membrane after about $\frac{1}{2} \mathrm{~h}$. The remainder eventually produced mainly normal blastulae even in size and appearance. At about the time of first cleavage equal quantities of eggs were distributed, from the appropriate washing waters, to the following sets of dishes.

$\begin{aligned} \text { Set } & \\ \text { I } & \text { Clyde sea water not sterile } \\ \text { II } & \text { Clyde sea water (A) proved almost sterile until used } \\ \text { III } & \text { Clyde sea water (B) proved almost sterile until used } \\ \text { IV } & \text { Clyde sea water (as I) }+10 \% \text { culture medium (control) } \\ \text { V } & \text { Clyde sea water (as I) }+50 \% \text { culture medium (control) } \\ \text { VI } & \text { Clyde sea water (as I) }+10 \% \text { culture filtrate } \\ \text { VII } & \text { Clyde sea water (as I) }+50 \% \text { culture filtrate } \\ \text { VIII } & \text { Artificial sea water } \\ \text { IX } & \text { Artificial sea water }+10 \% \text { culture medium (control) } \\ \text { X } & \text { Artificial sea water }+50 \% \text { culture medium (control) } \\ \text { XI } & \text { Artificial sea water }+10 \% \text { culture filtrate } \\ \text { XII } & \text { Artificial sea water }+50 \% \text { culture filtrate }\end{aligned}$

No. of dishes in set

For the first 2 days there were no observable differences between any of the dishes, the larvae swam up strongly in them all. The subsequent development of Sets I, II and III will be considered first. Three days after fertilization there was a slight tendency for the larvae in the dishes of Set II to concentrate at the surface more than in any other set, but this was not observed the next day though it re-occurred on the sixth day. It must be emphasized, however, that this tendency was never more than barely perceptible. There were no structural differences between the plutei of Sets I, II and III at any stage. They were in fine normal condition on the fifth day, but on the sixth the living tissues of the arms shrank down the supporting rods, which broke away leaving the larvae armless. The following day they were very abnormal in all three sets and many were dead.

The addition of culture medium and culture filtrate to the Clyde water (Sets IV to VII) made little difference. Such differences as were observed indicated that culture medium, when present in fair proportion as in Set V, was on the whole disadvantageous but in lower concentration (Set IV) was very slightly beneficial. The culture filtrate had even less effect.

In the artificial sea water (Set VIII) many of the larvae, which in the early stages swam up strongly, sank to the bottom of the dish a little earlier than in the natural sea waters in Sets I-III, but they did not degenerate quite so quickly as did those in the natural sea waters, although on the whole there was little difference. The addition of culture medium made only a very slight difference, being on the whole disadvantageous in quantity (Set X) and very slightly favourable in smaller amount (Set IX). Culture filtrate made little or no difference. 


\section{EXPERIMENT 7}

E I surface water collected 15. iii. 55. Ship: M.F.V. Sula with F.A.J.A. Dipped up with wooden bucket and strained through 200 -mesh bolting-silk into glass carboy. Plankton thicker than usual.

E I bottom water $(70 \mathrm{~m})$ collected same time as surface water using Perspex-lined water bottle. Stored in glass Winchester but not filtered through bolting-silk.

Echinus ground bottom water $(52 \mathrm{~m})$ collected same day as $\mathrm{E} I$ bottom water and in same way. This ground is situated Eddystone N. $160^{\circ}$, Rame Head N. $55^{\circ}$ E.

Clyde water (surface) collected 14. iii. 55, in Largs Channel. Small boat with $\mathrm{Mr}$ E. Latham. Strained through 200-mesh bolting-silk into glass carboy.

Artificial sea water. All waters were filtered in the laboratory through Berkefeld filter candles not more than I day before use.

The purpose of this experiment was to compare again E I and Clyde surface waters which of recent years had not been as strikingly different in their properties as they had been several years ago when the first experiments were made. It also was to investigate further the 1954 results in which it appeared that there was a difference between the surface and bottom water at E I, and that the development of the Echinus eggs was affected by the water in which the eggs were washed between fertilization and first cleavage (Expts. 3 and 4 ). As the bottom water at E I had apparently been unfavourable to the development of the eggs it was decided to test bottom water from the Echinus grounds themselves. These are situated some miles away from E I, (where the bottom is muddy and there are no sea-urchins) and the water bathing these grounds would be that into which the Echinus would spawn under natural conditions. It must in this connexion be remembered, however, that the water over the grounds would be changing and would not be static from day to day, and that it was impossible to know whether on the day chosen for taking the water any of the Echinus would be spawning naturally. If their spawning is affected by the particular type of water bathing them it is conceivable that only at certain times, when the water is favourable, do they actually shed their eggs and sperms.

The Echinus used were trawled on I8 March from beyond the Eddystone and not on the ground from which the Echinus bottom water had previously been taken and where Echinus is normally abundant. In March and April I955, perhaps as the result of the severe gales earlier, Echinus proved to be almost absent from this ground and they had to be got elsewhere when needed in quantity. This fact was not known when the bottom water was collected. The fertilization was made as soon as the urchins had been brought into the laboratory; the majority of the urchins were immature but a moderately mature female was found. The eggs and sperms were shed into, and the fertilization was made in, artificial sea water. The same urchins were subsequently spawned into, and a control fertilization made, in E I surface water; this was successful but not particularly good. About $\frac{3}{4} \mathrm{~h}$ after fertilization the cytoplasm of the eggs became irregular in outline (rather as in Expt. I), rounding up again 40 min later before first cleavage. Seven minutes after the fertilization in artificial sea water had been made the eggs from it were divided into five equal quantities into the five wash waters. Six changes of these were given and after the first cleavage eggs were distributed in equal quantities to the dishes containing the waters to be tested. There were twelve sets of these, three dishes to each set. The arrangement of the experiment will be clear from the headings in Table I. Thus Set I comprised three dishes each containing $100 \mathrm{ml}$. of E I surface water and into them equal quantities of eggs were ladled out of the beaker in which they had been washed with E I surface water to free them from the artificial sea water in which the fertilization had been made. Set II likewise 
comprised three dishes each containing $100 \mathrm{ml}$. of E I surface water, but into these were put equivalent quantities of eggs washed in $\mathrm{E}$ I bottom water (and with them about $8 \mathrm{ml}$. of the latter water from which they could not be separated), and so on through the whole series. The condition of the larvae on subsequent days is recorded in Table ' $\mathrm{I}$. First, their swimming vigour as shown by the relative numbers at the surface and bottom, and as evenly distributed in mid-water between surface and bottom, and secondly on the fourth day and thereafter the structural appearance of the plutei is briefly described, together with rough estimates of the numbers observed to have died. There were never any differences between the three dishes of any one set; in so far as they differed from those of another set they all differed alike. Not until after $23 \mathrm{March}$, on which day the experiment was considered to have ended, did any inconsistencies appear between dishes of the same set and then only to a slight extent. These later stages are not recorded for they were concerned only with farther degeneration and death and did not yield any more information about the waters.

There are several interesting features to be noted concerning the results. It was very noticeable that on the morning of the second day the blastulae swam up more strongly in the Clyde water (Sets VI-X) than in any of the others and in the artificial sea water (Set XII) not at all. On the third day they were swimming well in all dishes but most strongly in both the bottom waters (Sets IV, V, X and XI), while the larvae in the Clyde waters which previously had led now flagged a little, there being more on the bottom than in any of the others and slightly fewer at the surface also. This latter fact is not indicated in the Table for the numbers involved were too few to justify recording a lower category than that shown. By the next day the larvae in the Clyde waters had caught up again with the others, and as regards swimming vigour all dishes were equal except those containing artificial sea water (Set XII) where almost all the larvae, which were structurally abnormal, had sunk to the bottom. These larvae never formed normal plutei although retentive of life. On 2I March the larvae of one dish were transferred to Clyde water and one other to artificial sea water and Clyde water in equal proportions. The following 2 days more larvae swam up off the bottom of these dishes than did those in the remaining dish of artificial sea water only (which alone is recorded in Table 2 for 22 and 23 March), but they never showed any indication of developing into plutei. On 2I March it was observed for Sets I-XI that the larvae, which were early plutei beginning to grow their first four arms, were decidedly more advanced in development with longer arms and were healthier looking in the Clyde waters than in any of the others. The larvae in all other natural waters looked much alike, except that possibly those in the Echinus ground bottom water (Sets X and XI) were a trifle better than those in the E I waters, both surface and bottom.

The next 2 days, 22 and 23 March, showed some marked differences. It became clear that Clyde water (Set VI) was proving a better medium for the larvae than E I surface water, and to an extent similar to that which existed a few years ago. It was clear too, that whilst washing the eggs between fertilization and first cleavage had not affected them when the wash water was E I surface water (Set VII), it had had an adverse effect when this wash water had been either of the bottom waters (Sets VIII and IX), especially the Echinus ground bottom water. This latter water although at first promoting swimming vigour did not long support the larvae in health (Sets X and XI) and finished by being almost worse in this respect than any other natural water. It had also proved bad when used as a wash water for eggs placed subsequently in E I surface water (Set III). The E I surface water itself, had not, as has been seen, given good plutei at any stage, the eggs which had been washed with $\mathrm{E}$ I bottom water (Set II) doing slightly better than others washed differently (Sets I and III), whilst the E I bottom water itself was slightly better (Sets IV and V) than the surface water from 
TABLE 1. EXPERIMENT 7, FERTILIZATION OF ECHINUS ESCULENTUS MADE IN ARTIFICIAL SEA WATER ON 18 MARCH 1955

\begin{tabular}{|c|c|c|c|c|c|c|c|c|c|c|c|c|}
\hline Set & I & II & III & IV & $\mathrm{v}$ & VI & VII & VIII & IX & $\mathrm{x}$ & XI & XII \\
\hline Water in dishes & E I surface & E I surface & E I surface & E I bottom & E I bottom & Clyde surface & Clyde surface & Clyde surface & Clyde surface & $\begin{array}{l}\text { Echinus ground } \\
\text { bottom }\end{array}$ & $\begin{array}{l}\text { Echinus ground } \\
\text { bottom }\end{array}$ & $\begin{array}{l}\text { Artificial sea } \\
\text { water }\end{array}$ \\
\hline Wash water & (E I surface) & (E I bottom) & $\begin{array}{l}\text { (Echinus } \\
\text { ground } \\
\text { bottom) }\end{array}$ & (E I surface) & (E I bottom) & (Clyde surface) & (E I surface) & (E I bottom) & $\begin{array}{c}\text { (Echinus } \\
\text { ground } \\
\text { bottom) }\end{array}$ & (E I surface) & $\begin{array}{l}\text { (Echinus } \\
\text { ground } \\
\text { bottom) }\end{array}$ & $\begin{array}{l}\text { (Artificial sea } \\
\text { water) }\end{array}$ \\
\hline 19. iii. 35 (a.m.) & $\begin{array}{l}\text { Beginning to } \\
\text { swim up }\end{array}$ & As I & As I & As I & As I & $\begin{array}{l}\text { Swimming up } \\
\text { strongly }\end{array}$ & As VI & As VI & As VI & As I & As I & All on bottom \\
\hline 20. iii. $55 \underset{\substack{M \\
\underset{B}{M}}}{S}$ & $\begin{array}{l}\text { *** } \\
* * * * \\
* * *\end{array}$ & As I & As I & $\begin{array}{c}* * * * * \\
* * * \\
* *\end{array}$ & As IV & $\begin{array}{l}* * * * \\
* * * * * \\
* * * *\end{array}$ & As VI & As VI & As VI & $\begin{array}{c}* * * * * \\
* * * \\
* *\end{array}$ & As $\mathrm{X}$ & $\begin{array}{l}* * * * \\
* * * \\
* * *\end{array}$ \\
\hline 21. iii. $55 \underset{M}{\stackrel{S}{S}}$ & $\begin{array}{l}* * * * \\
* * * * \\
* * * * \\
\text { Fairly good, } \\
\text { very few } \\
\text { abnormal }\end{array}$ & $\begin{array}{l}\text { As I } \\
\text { As I }\end{array}$ & $\begin{array}{l}\text { As I } \\
\text { As I }\end{array}$ & $\begin{array}{l}\text { As I } \\
\text { As I }\end{array}$ & $\begin{array}{l}\text { As I } \\
\text { As I }\end{array}$ & $\begin{array}{l}\text { As I } \\
\text { Good, very } \\
\text { few abnor- } \\
\text { mal }\end{array}$ & $\begin{array}{l}\text { As I } \\
\text { As VI }\end{array}$ & $\begin{array}{l}\text { As I } \\
\text { As VI }\end{array}$ & $\begin{array}{l}\text { As I } \\
\text { As VI }\end{array}$ & $\begin{array}{l}\text { As I } \\
\text { As I }\end{array}$ & $\begin{array}{l}\text { As I } \\
\text { As I }\end{array}$ & $\begin{array}{c}* \\
\underset{*}{*} * * * * \\
\text { Abnormal }\end{array}$ \\
\hline 22. iii. $55 \underset{\substack{M \\
B}}{S}$ & $\begin{array}{l}\text { * } \\
\text { *** * * * * } \\
\begin{array}{l}* \text { Poor, often } \\
\text { abnormal, } \\
\text { few dead }\end{array}\end{array}$ & $\begin{array}{l}* * * \\
* * * * \\
* * * * * \\
\text { A little better } \\
\text { than in I, } \\
\text { few dead }\end{array}$ & $\begin{array}{l}\quad * * \\
* * * \\
* * * * * * \\
\text { Poor, many } \\
\text { abnormal, } \\
\text { several } \\
\text { dead }\end{array}$ & $\begin{array}{l}\text { **** } * \\
\text { ***** } \\
\text { ***** } \\
\text { Moderate, fair } \\
\text { number ab- } \\
\text { normal }\end{array}$ & $\begin{array}{l}\int_{\mathrm{r}} \text { As IV } \\
\text { As IV }\end{array}$ & $\begin{array}{l}\text { ****** } \\
\text { ****** } \\
\text { *** * * } \\
\text { Good, very } \\
\text { few abnor- } \\
\text { mal, very } \\
\text { few dead }\end{array}$ & $\left\{\begin{array}{l}\text { As VI } \\
\text { As VI }\end{array}\right.$ & $\begin{array}{c}\text { *** } \\
\text { ***** } \\
\text { ***** } * \text { * } \\
\text { Moderate, good } \\
\text { number ab- } \\
\text { normal, } \\
\text { several dead }\end{array}$ & $\begin{array}{c}* * * * \\
* * * \\
* * * \\
\text { Fairly good, } \\
\text { good number } \\
\text { dead }\end{array}$ & $\begin{array}{l}\text { ** } \\
\text { *** } \\
\text { * * * * * * } \\
\text { rate, made- } \\
\text { abnormal, } \\
\text { several dead }\end{array}$ & $\begin{array}{c}\text { *** } \\
\text { ******* } \\
\text { As } \text { X }^{*} *+\end{array}$ & $\begin{array}{c}* \text { - } \\
\text { * } \\
\text { * * * * * * * } * \\
\text { mal }\end{array}$ \\
\hline 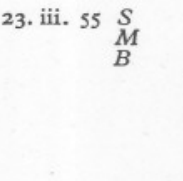 & $\begin{array}{l}\text { ० } \\
\text { *- } \\
\text { ***** * * * } * \text { poor, all } \\
\text { Very pormal, } \\
\text { abnormal } \\
\text { good number } \\
\text { dead }\end{array}$ & $\begin{array}{l}\text { * } \\
\text { ** * * * * * } \\
\text { Poor, mostly } \\
\text { abnormal, } \\
\text { good number } \\
\text { dead }\end{array}$ & $\begin{array}{c}\circ \\
\circ \\
\text { * * * * * * } \\
\text { All abnormal, } \\
\text { dead or } \\
\text { dying }\end{array}$ & $\begin{array}{l}*- \\
* * \\
\text { * } * * * * *+ \\
\text { Slightly better } \\
\text { than II, but } \\
\text { very similar }\end{array}$ & $\begin{array}{l}\} \text { As IV } \\
\text { Poor, mostly } \\
\text { abnormal, } \\
\text { good num- } \\
\text { ber dead }\end{array}$ & $\begin{array}{l}\text { *** } \\
\text { **** * * * * } \\
\text { Moderate, } \\
\text { majority be- } \\
\text { coming ab- } \\
\text { normal, few } \\
\text { dead }\end{array}$ & $\begin{array}{l}\text { As VI } \\
\text { As VI }\end{array}$ & $\begin{array}{c}* \\
* * \\
* * * \\
\text { Slightly in- } \\
\text { ferior to VI }\end{array}$ & $\begin{array}{l}\text { * } \\
\text { * } \\
\text { * * * * * * + } \\
\text { Very poor, all } \\
\text { abnormal, } \\
\text { many dead }\end{array}$ & $\begin{array}{c}*- \\
* \\
\text { All abnormal, } \\
\text { majority } \\
\text { dead }\end{array}$ & $\begin{array}{l}\circ \\
\circ \\
\text { *** * * * * + } \\
\text { Very abnormal, } \\
\text { almost all } \\
\text { dead }\end{array}$ & $\begin{array}{c}\circ \\
\circ \\
* * \\
\text { Very abnormal, } \\
\text { several dead }\end{array}$ \\
\hline
\end{tabular}

$B=$ bottom; $M=$ mid-water; $S=$ surface. $O=$ none; $*-=$ very few; $*=$ few; $* *=$ several; $* * *=$ fair number; $* * * *=$ good number; $* * * * *=$ many; $* * * * *+=$ very many. 
the same position. This is the reverse of the 1954 findings with $\mathrm{E} I$ waters (see p. 335). It must be emphasized that all these differences although definite were slight; they were not of the order of the difference between the Clyde water and all the others.

The results standing out from this experiment are: (I) the superiority of Clyde water over all the others, although the plutei were never as well developed or as long lived in it as had sometimes been the case in earlier experiments. This may have been a reflexion of the quality of the eggs or sperm but this point was not controlled. (2) The inability of the eggs to form normal larvae in the artificial sea water, in contradistinction with those reared in artificial sea water in previous years. It may be noted that the sodium chloride used in making up the artificial sea water came this year from a different batch than before. (3) The fact that every difference in the treatment of the eggs, the water they were washed with and the water they developed in had some influence, however slight, on the structure and health of the larvae developing from the eggs, and these differences affected all dishes of a set equally.

\section{EXPERIMENT 8}

Celtic sea surface water collected 9. iv. 55. Position $50^{\circ}$ N. $10^{\circ}$ W. R.V. Sarsia with $\mathrm{Mr}$ A. D. Mattacola. Strained through 200-mesh bolting-silk into glass carboy. At the same time two further samples (A and B) were collected through Doulton candles into evacuated sterile Winchesters using the method described in Wilson \& Armstrong, 1954, pp. 348-9.

E I surface water collected I2. iv. 55. M.F.V. Sula with F.A.J.A. Strained through 200-mesh bolting-silk into glass carboy. At the same time two further samples (C and D) were collected through Doulton candles into evacuated sterile Winchesters.

Artificial sea water as used in Expt. I.

As usual the carboy waters were filtered in the laboratory before use, Doulton candles being used. The waters filtered through similar candles at the time of collection were tested for sterility shortly before use and three of them, two being from E I and one from the Celtic sea proved to be sterile. We were again indebted to Dr C. H. Jellard of the Public Health Laboratory Service for making the bacteriological tests.

The urchins were trawled on 14 April and used as soon as they arrived in the laboratory. They had unfortunately proved scarce and there were therefore fewer than usual from which to select. The male and female chosen gave what appeared to be an almost $100 \%$ perfect fertilization with well-elevated membranes and perfect first and second cleavage. There was no crumpling of the cytoplasm before cleavage, as occasionally noted previously. The fertilization was made in artificial sea water and immediately divided into ten equal parts, each part in a small beaker, and each part was then washed with four changes of one of the waters to be tested, as recorded below. After first cleavage the eggs were distributed to the following sets of dishes, three dishes to a set. The eggs supplied to Sets XI and XII were washed between fertilization and first cleavage in a water other than that to which they were finally transferred, but were subject to further washing after first cleavage to avoid adding to the water in the dishes even a little of another sort as had been done in some earlier experiments.

In spite of the apparent excellence of the fertilization up to and including the second cleavage at 9 p.m. on the first evening, almost all the eggs died in later cleavage stages and by the next morning relatively few had survived to form normal blastulae. All natural waters (Sets I-VI and XII) were equal in these respects, but in the artificial waters (Sets VII-XI) only about half were dead, the remainder being living blastulae, many obviously abnormal. These never developed into plutei, as in artificial sea water in the previous experiment, and the addition of the extracts made no difference whatever. 
Water tested. Except where otherwise stated four washings with the same water were given between fertilization and first cleavage

I EI surface water (carboy)

II EI surface water proved sterile until used (Winchester C)

III E I surface water proved sterile until used (Winchester D)

IV Celtic sea surface water (carboy)

V Celtic sea surface water proved sterile until used (Winchester A)

VI Celtic sea surface water filtered at time of collection but not sterile when tested (Winchester B)

VII Artificial sea water

VIII Artificial sea water with added blank extract

IX Artificial sea water with added E I extract

X Artificial sea water with added Clyde extract

XI Artificial sea water-eggs in Celtic water between fertilization and first cleavage, then washed with artificial sea water

XII EI surface water (carboy) - eggs in artificial sea water between fertilization and first cleavage, then washed with EI surface water

With so few left alive in the natural waters definite results are hardly to be expected. At most it can be said that slightly fewer larvae swam up in the sterile Sets II and III than in Set I, and the same thing can be said of Sets V and VI compared with Set IV, although Set VI was not actually sterile. These differences were very slight. There were no distinctions between Celtic and E I waters and the best larvae were poor stunted plutei which never properly grew arms. On the fifth day all those living were very abnormal everywhere and the experiment was abandoned.

There seems little doubt that the fertilized eggs had been incapable of normal development; they did badly in all waters. The experiment is, however, of value in that it indicates that the new type of extract is not poisonous, as had previously been the case with carbon and acetone extractions (Wilson \& Armstrong, 1954, pp. 35I, 355), and this may in future prove to be a useful method of investigating the main problem. It may be useful, too, to put on record that the method devised for obtaining sterile sea water at the time of collection was again successful, and on this occasion three times out of four.

\section{EXPERIMENT 9}

It was impossible to repeat again Expt. 8 the same year on account of the organization needed and the fact that no ship would be available to do the necessary collecting until after the end of the breeding season of Echinus esculentus. Indeed, for the time being no more sea-urchins could be got and so recourse was had to using Sabellaria alveolata, the larvae of which had previously responded to water differences, though not as readily as Echinus larvae (Wilson, I95I, p. I4). It seemed desirable at least to test the Celtic and the E I carboy waters used in Expt. 8 to make as sure as possible that the failure of that experiment should be attributed to the condition of the eggs and not to the waters.

On 24 April 1955 Sabellaria alveolata was collected at Duckpool, near Bude. On 27 April a fertilization (several males and females) was made in a mixture of the same Berkefeld filtered Celtic and E I carboy waters used in Expt. 8. After fertilization the eggs were divided equally into four beakers and each given several changes of one of the following four waters.

$\begin{array}{rll}\text { Set } & \\ \text { II } & \text { Aquarium water (unfiltered) } \\ \text { II } & \text { Celtic water } \\ \text { III } & \text { E I water } \\ \text { IV } & \text { Artificial sea water }\end{array}$


The following day in each beaker all larvae which had swum to the surface were decanted off from unripe eggs on the bottom, and approximately equal quantities of these larvae distributed to the experimental dishes, three dishes in each set.

Until 30 April no significant differences were observed between any of the sets. On that day the larvae in the artificial sea water, which was an unused quantity remaining over from Expt. 8, were seen to be swimming more slowly than in the other sets, and they were not so well developed or as large as the larvae in the natural sea waters. This difference persisted until the experiment was abandoned a week later, by which time larvae in the artificial sea water were losing spines and many were dead. Throughout this time no differences appeared between the other sets of larvae, they developed well for a time and until checked by lack of food.

From these observations it appears that the Celtic and EI carboy waters were almost certainly not responsible for the high mortality in Expt. 8. It is also interesting to note that whereas the Echinus eggs in the two previous experiments had in artificial sea water failed to produce anything resembling a normal pluteus, the Sabellaria eggs in the same artificial sea water developed into larvae structurally normal so far as could be observed, except that they were smaller than those in the natural waters and swam more slowly.

\section{DISCUSSION}

The factor which has hampered our experiments more than any other has been the weather. Much initial planning and much careful preparation has been wasted and several experiments have been largely ruined because storms at critical times have prevented the collection of water samples. Storms also had their effect on the collection of Echinus, and as in I955 gales in the weeks preceding the breeding period may, or so it appears, have an adverse effect on the numbers of sea-urchins present on the local grounds and perhaps even on the maturity of those still left there. It was particularly unfortunate, in this connexion, that, when, as for Expt. 8, a number of bacteria-free samples of water had been successfully collected from two localities the fertilization, at first seemingly excellent, failed to produce good larvae in any water, apparently because the zygotes were incapable of development beyond early cleavage, it being unlikely that the natural waters themselves were to blame (see Expt. 9). In the face of such hindrances by natural forces progress in this type of work is likely to continue to be very slow.

It is perhaps not surprising that bottom and surface waters at the same station should affect the developing eggs differently, for it is normal for such waters to be distinguishable chemically. What is surprising is that bottom water should often have proved harmful, especially when the eggs were exposed to it for only a short period following fertilization. It is at this period that eggs would normally be in bottom water after having been shed. It may be that this effect is due to experimental conditions, such as rapidly substituting one water for another. It can hardly be a temperature effect because all waters used were brought to a uniform temperature. If it is real it is a pointer to the possibility that bottom animals may spawn only when the water 
in which they are bathed is suitable for development. In one experiment the bottom water was as good as, if not better than the surface water.

These results and those with mud extracts may be linked with the need of the developing echinoderm egg and larva to absorb substances from the surrounding medium (Needham, I93I) and it may be necessary for some of these substances to be absorbed very soon after fertilization. The experiments do not indicate that there is anything in filtrates (which contained some natural sea water) from diatom or flagellate cultures, or from culture medium itself, which can supply those needs.

The most interesting criticisms (Walne, I956, and private discussions with others) which have arisen in the course of our work concern the possible effects of bacteria on the waters collected during the inevitable storage period between collection and use, and of excessive bacterial growths in the experimental dishes during the course of the experiments ${ }^{\star}$. Moreover, these criticisms seemingly always imply that such bacteria produce harmful effects and it does not appear to have been envisaged that they may sometimes be beneficial, if not essential. In saying this we do not wish to imply that we believe that we have any real evidence that bacteria are beneficial: we approach the problems posed by their presence with completely open minds. None the less we do believe that differing bacterial populations would be no more than another demonstrable difference between disimilar water masses and not necessarily in themselves the basic cause of those differences. For the basic cause we must look even further back, behind the bacteria.

In our experiments we have, as recorded in the preceding pages and in an earlier paper (Wilson \& Armstrong, 1954), endeavoured to filter water free from bacteria at the time of collection and to compare larvae reared in such water with those reared in water collected at the same time in the usual manner, using as a filter nothing finer than bolting-silk. A modicum of success has attended these efforts but the results obtained are open to varying interpretation. However, so far as they go they do not support the view that bacteria in the water between collection and use make it less suitable for the larvae reared in it: on the contrary such slight differences as were shown between bacteria-free samples and their corresponding waters collected in the ordinary way (carboy waters) were úsually in favour of the latter. It is possible that the slightly unfavourable results obtained with the bacteria-free waters are explicable by contact of the water with the previously heated rubber tubing through which it was passed and from out of which substances may have dissolved; also water stored in a Winchester has a larger surface area of glass in contact with it, volume for volume, than has water in a carboy. In future experiments these details should be equalized on both sides. Even

* See also Walne, I958 (this Number, p. 415). Although Walne's latest paper was not seen by us until after this discussion had been written, we feel that it already answers the chief points raised by Walne. 
as it was, the difference between the two samples of one kind of water collected in the two ways was always much less than the differences which have often been observed between waters from separate localities.

Our bacteria-free waters were, of course, free from bacteria only until they were poured out into the experimental dishes and the eggs put into them. Presumably, at that time they had a smaller population of bacteria than did the corresponding carboy-collected water, although perhaps not so much smaller because this latter water was itself passed through filter-candles not many hours before use. Walne (1956) has recently shown how in vessels each containing I 1. of sea water twice filtered through filter-candles, and to which were added a few $\mathrm{ml}$. of concentrated Isochrysis culture together with several hundred oyster larvae, the concentration of bacteria increased during the first 3 or 4 days of the experiments. Presumably more or less the same thing must have happened in our dishes, but no bacterial counts were made. Certainly if some of the larvae died after a few days the water in the dishes became slightly cloudy, but it is difficult here to distinguish between cause and effect: did the bacteria increase because larvae died and decayed, or did the larvae die because the bacteria increased? Walne found that in five of his six successful rearings the bacterial peak numbers were markedly lower than in his unsuccessful rearings, and suggests that the bacteria may have been influencing the successful development of his larvae, although there was no definite proof of this. He concludes that 'differences which have been observed in the value of different natural waters for rearing larvae may have their origin in the variation in the size of the bacterial flora which the water can support'. In other words the effect on the larvae of water differences is indirect via the bacteria, but it is none the less true that the waters themselves have different properties, though it may be that these only affect larvae in the confines of a dish where the bacterial population per unit volume rises higher than is possible in the open sea. Whilst this could be so it should be remembered that real changes of fauna have taken place in areas where there have been known changes of water masses and, in default of any more reasonable explanation, it would be rash to conclude that there is no real relation between the inability of water in a dish to support larvae and the larval supporting capacity of the same kind of water in the sea.

Some observations which may have a bearing on this question of the effect of excessive bacterial growths in dishes of developing larvae were mentioned in a previous paper (Wilson \& Armstrong, I954, p. 357). The antibiotics penicillin and streptomycin in various concentrations added to the water had no definite effects on the larvae, but as no bacterial counts were made it is not known whether they had any effect in reducing the bacterial flora. It may perhaps be assumed that they had, for Spencer (1952, p. I00) states that at the concentration of penicillin we used bacterial growth in peptone sea water was inhibited for many days. 
Whether the bacteria are the directly responsible agents for the observed structural defects in larvae reared in unfavourable waters or not, it cannot be too strongly emphasized that the effects on the larvae are but a reflexion of real differences between the waters themselves, though of what those basic differences are we are still ignorant. In any experiment in which waters are compared, natural sea waters treated or untreated, or artificial sea waters, nothing is more striking than the uniformity of appearance in structure and movement of the larvae in all the dishes containing the same kind of water. Only on very rare occasions during the first days is there an odd dish not in conformity with the others of the same set. Larvae in another set of dishes containing a different sort of water may or may not look different from these, but if any one dish of that set is at variance so are all the rest and in the same way. Therefore we cannot but conclude that the larvae are affected structurally, and in other ways, by the water in which they develop and that we can use these larvae as test objects, though we do not as yet know what properties of the water we are testing with them, or how far we can safely apply our results to what happens naturally in the open sea.

Of the many experiments we have made we believe that the tests with mixed waters (Wilson, 195I, Expts. 5 and 8A; Wilson \& Armstrong, 1952, Expt. I) are especially significant. It will be recalled that when good and bad waters were mixed in approximately equal proportions the larvae de veloping in the mixtures were closely similar to those in good waters alone and much better than those in the bad waters. Any hypothesis advanced to explain our results must account for this.

\section{SUMMARY}

In 1954 and 1955 various natural, artificial and treated sea waters were tested with developing eggs of Echinus esculentus. The following are the main observations:

I. Sea waters filtered through Doulton candles at the time of collection and proved bacteriologically sterile until use were very little different from sea waters collected at the same time in the ordinary way and not sterile. (Expts. I, 3,8 and, with qualifications, 6 .)

2. Undiluted Celtic sea bottom water and undiluted Celtic mud 'extract' were harmful to the eggs, but small volumes of both added to natural sea waters and to artificial sea water had a stimulating effect. (Expt. I.)

3. In water from near the bottom at E I eggs did worse, in I954, than in surface water from the same locality. In 1955 they did slightly better in the deeper water. (Expts. 3, 4 and 7.)

4. Eggs placed immediately after fertilization in water from near the bottom at E I (and from near the bottom at the Echinus ground) and transferred at first cleavage to surface waters were affected unfavourably. (Expts. 3, 4 and 7.) Artificial sea water had no such effect. (Expt. 5.) 
5. The addition to natural and to artificial sea waters of filtrates from culture medium ('erdschreiber') and from thick cultures of diatoms and flagellates had no significant effects on the eggs developing in those waters. (Expt. 6.)

6. In I955 surface water from the Clyde was a better medium for development than surface water from $\mathrm{E} \mathrm{I}$. The difference was similar to that frequently observed several years previously. (Expt. 7.)

7. Extracts of natural sea waters made by a new process were non-poisonous, but the experiment in which they were added to artificial sea water was inconclusive owing to the eggs proving to be of poor quality. (Expt. 8.)

\section{REFERENCES}

NeEdham, J., I93I. Chemical Embryology, Vols. 2 and 3. Cambridge.

SPENCER, C. P., I952. On the use of antibiotics for isolating bacteria-free cultures of marine phytoplankton organisms. F. mar. biol. Ass. U.K., Vol. 31, pp. 97-I06.

WALNE, P. R., 1956. Bacteria in experiments on rearing oyster larvae. Nature, Lond., Vol. 178, p. 9 I.

WIIson, D. P., I951. A biological difference between natural sea waters. F. mar. biol. Ass. U.K., Vol. 30, pp. I-26.

WIISON, D. P. \& ARMSTRONG, F. A. J., 1952. Further experiments on biological differences between natural sea waters. F. mar. biol. Ass. U.K., Vol. 31, pp. 335-49. 1954. Biological differences between sea waters: experiments in 1953. F. mar. biol. Ass. U.K., Vol. 33, pp. 347-60. 